\title{
STATUS OF FISHERY IN THE CHILAW ESTUARY
}

\author{
S.J.C. JAYAWICKREMA \\ National Aquatic Resources Agency, Crow Island, Mattakkuliya, Colombo 15.
}

(Date of receipt $:$ 24 December 1990)
(Date of acceptance $: \quad 6$ April 1992)

\begin{abstract}
The status of fishery in the Chilaw Estuary was studied during the period of October 1985 to September 1986. About fifteen species of fin fish, four species of prawns and the lagoon crab were fished in commercially important quantities. The total production of this lagoon was estimated at $150.4 \mathrm{mt} / \mathrm{yr}$ or $83.55 \mathrm{~kg} / \mathrm{ha}$.yr. The productivity is higher than those recorded for the Negombo estuary and the Puttalam lagoon.
\end{abstract}

\section{INTRODUCTION}

Sri Lanka has a coastline of approximately $1760 \mathrm{~km}$ and a continental shelf area of about $31,000 \mathrm{~km}^{2}$. There are approximately 121,460 ha of lagoons, estuaries and backwaters of which about a one quarter are lagoons. These are highly productive ecosystems. ${ }^{1}$ Lagoons and estuaries are important as nursery grounds for a number of species of fin fish and crustaceans.

There is some documented information on the productivity of coastal ecosystems. Schuster has estimated the average natural production of Sri Lankan lagoons to be around $22 \mathrm{~kg} \mathrm{ha} / \mathrm{yr}{ }^{2}{ }^{2}$ Pillai has estimated the natural production of Negombo estuary to be $72.9 \mathrm{~kg} / \mathrm{ha} . \mathrm{yr}^{3}$. Wijeyaratne and Costa have estimated the total annual production of all fin fish species of Negombo estuary to be around $15 \mathrm{~kg} / \mathrm{ha}$. According to Jayasuriya the estimated total production of Puttalam lagoon is 49 $\mathrm{kg} / \mathrm{ha.yr} .^{5}$

Penaeid prawns spend the early part of their life cycle in the lagoons. Post larvae enter the lagoons for feeding and the sub-adults migrate back to the sea. ${ }^{6}$

Although there is no published information on the productivity of the Chilaw estuary, is a general belief that the Chilaw estuary is less produtive than the Negombo estuary and Puttalam lagoon and is less intensely fished (Pers. comm. with fishermen). But it is the nursery gound for prawn obtained from the trawling grounds around Chilaw. These grounds are highly productive. ${ }^{?}$ They have estimated the standing stock biomass of many species of prawns such as Penaeus indicus, $P$. semisulcatus, $P$. monodon, Metapenaeus dobsoni and Parapenaeopsis stylifera to be $3133 \mathrm{~kg}, 1095 \mathrm{~kg}$, $313 \mathrm{~kg}, 2509 \mathrm{~kg}$ and $1764 \mathrm{~kg}$ respectively. More than one hundred 3.5 ton mechanized crafts operate here. 
There is little information available on the productivity of Chilaw lagoon. The present work was carried out during the period of October 1985 to September 1986 in an attempt to understand the status of the fishery in this estuary.

\section{MATERIALS AND METHODS}

The area of the Chilaw lagoon is around $1800 \mathrm{ha}^{8}$ Although Chilaw lagoon is termed a lagoon, it is in fact a basin estuary. There are two outlets to the sea; one at Thoduwawa and the other near the Chilaw market. There are two fresh water inlets the Lunu Oya and the Deduru Oya in the lagoon (Figure 1).

During the study three major landing sites were selected as representative of the estuary. These are Pambala, Chilaw market and Karukkupane. These sites were selected as they cover the southern, middle and the northern parts and represent the whole lagoon fishery. Each landing site was visited twice a month. Data were collected on the following:

1. catch by species

2. types of craft

3. total number of crafts operated

4. types of gear used

\section{Landing centres}

Pambala - This is situated in the southern part of the Chilaw estuary: Three sites which are Pambala, Marawala and Bandarawatte in the Pambalarea were sampled. The catch recorded has been taken as a total of Pambala area. Different types of gear such as drift nets, cast nets, vallachchal nets (nets operated by two canoes), brush piles and crab traps are used. The catch consisted of fin fish, prawns and crabs.

Chilaw market - Catch landed at many minor landing sites such as Ambakanthawila and Iranawila are brought to this central market. The catch from drift nets, cast nets, "seriya-del", stake seines and crab traps were sampled, in this centre. As the catches are landed beside the market, the catch obtained by different gear could be sampled.

Karikkupane- This is situated in the Northern part of the lagoon. The main types of fishing gear used are drift nets, cast nets, seriya del, stake seines, brush - piles and crab traps. All these were sampled for fin fish, prawns and crabs.

The catches obtained by different gears were sampled separately. By analysing the data obtained on two days each month from each landing centre, the total monthly production for each gear type, was estimated, from the following formula. 
Fishery in Chilaw Estuary

201

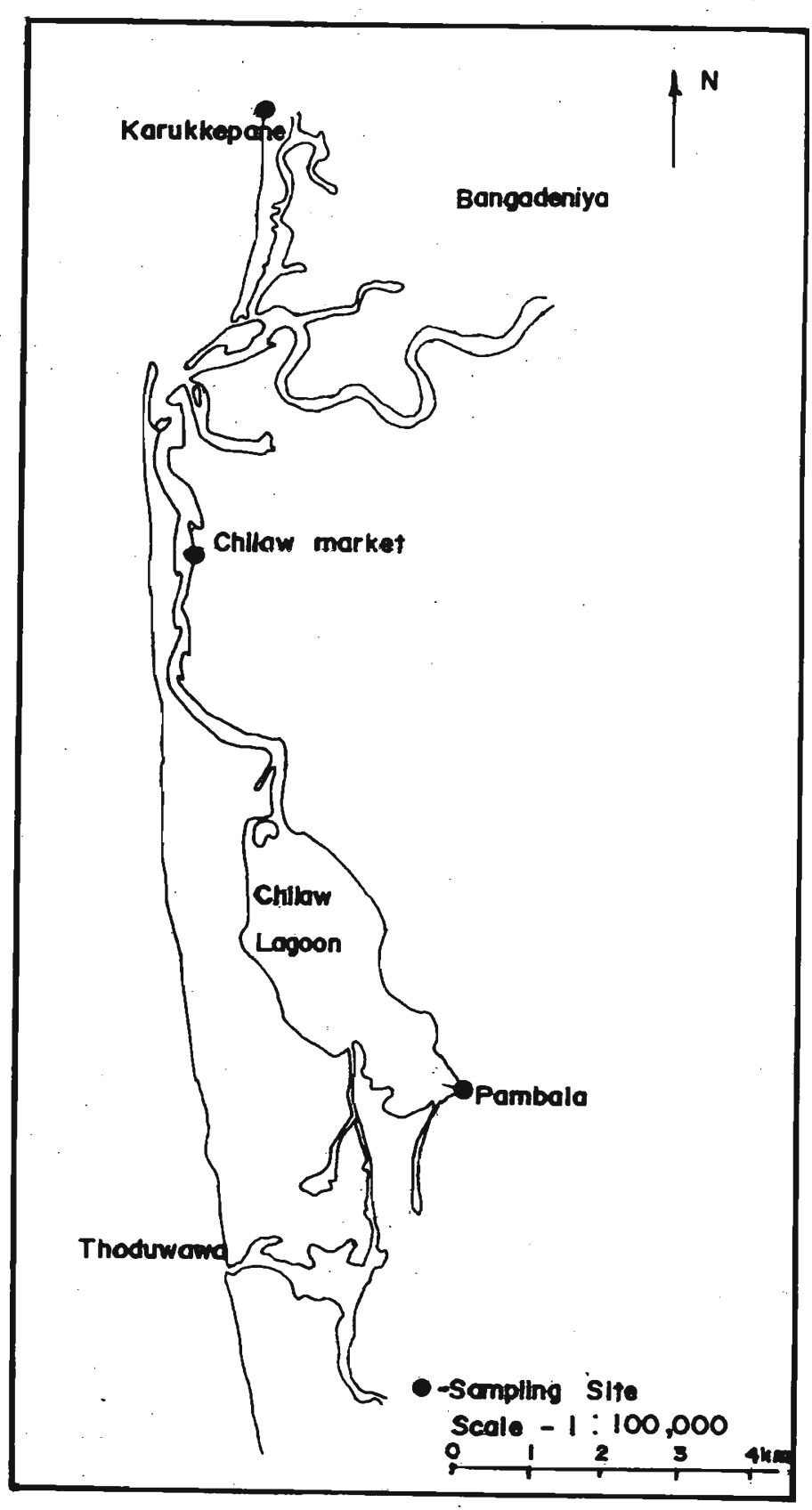

Figure 1: A map of the Chilaw estuary showing major landing sites. 


$$
Y_{\mathrm{i}}=D \sum_{\mathrm{j}=1}^{\mathrm{d}} \frac{L_{i j}}{I_{i j}} \sum_{\mathrm{k}=1}^{\mathrm{I}_{\mathrm{ij}}} Y_{i j k}
$$

$\mathrm{Y}_{\mathrm{i}}=$ Estimated monthly production of one type of gear at the $\mathrm{i}^{\text {th }}$ center.

$\mathrm{D}=$ No. of fishing days

d $=$ No. of days sampled

$\mathrm{L}_{\mathrm{ij}}=$ No. of gears operated at $\mathrm{i}^{\text {th }}$ centre on $\mathrm{jth}$ day

I $=$ No. of gears sampled at $\mathrm{i}^{\text {th }}$ centre on $\mathrm{jth}$ day

$\mathrm{Y}_{\mathrm{ijk}}=$ Landings of $\mathrm{kth}$ craft on $\mathrm{j}^{\text {th }}$ centre

Then,

$$
Y=M \times \frac{y}{M_{\mathrm{i}}}
$$

where,

$\mathrm{Y}=$ Estimated total monthly production

$M=$ Number gear in the $\mathrm{i}^{\text {th }}$ centre

$\mathrm{M}_{\mathrm{i}}=$ Total number of gears in the lagoon

\section{RESULTS}

The major species of fin fish caught in the descending order of occurrence in the catch are silver bellies (consisting of Secutor insidiator, Leiognathus fasciatus and $L$. splendens), Mugil sp., Arits sp., Labeo porcellus lankae, Acanthopagnus berda, Earangids (such as Atule mate and Carangoides praeustus), Lates calcariifer, Sillago sihama, Etroplus suraterisis and Macrura kelle. The fin fish comprised brackish water, freshwater and marine species as the lagoon opens to the sea as well as having fresh water inlets.

The shell fish comprised mainly penaeid prawns and crabs. Macrobrachium rosenbergii was also caught in a few instances. The prawn catch was dominated by Penaeus indicus followed by $P$. monodon, $P$. semisulcatus and Metapenaeus dobsoni. The lagoon crab Scylla serrata was also caught mainly by crab traps.

The monthly variation of the estimated total production of prawns, fish and crabs in presented in Figure 2.

The prawns show peaks in the catches in months of February and September and the catches are low in May and August. The highest production of fin fish was observed in June. Crabs show peaks in February and July. The monthly variation of the estimated production of prawns, fish and crabs in the three stations sampled are 
presented separately in Figures 3, 4 and 5. The highest catches were observed in the Chilaw market.

Table 1: The relative contribution to the annual yield by each major fin fish variety caught in the Chilaw estuary.

\begin{tabular}{lcc}
\hline \multicolumn{1}{c}{ Species } & $\begin{array}{c}\text { Amount of } \\
\text { fish caught } \\
(\mathrm{kg})\end{array}$ & Percentage \\
\hline Silver bellies: & 11793.6 & 24.0 \\
(Secutor sp., Leiognathus sp. etc.) & 7960.7 & 16.2 \\
Mugil sp. & 7764.1 & 15.8 \\
Arius sp. & 2506.1 & 5.1 \\
Labeo porcellus lankae & 1670.7 & 3.4 \\
Acanthopagnis berda & 1081.0 & 2.2 \\
Erangids: & & \\
(Atule sp., Carangoides sp. etc.) & 982.8 & 2.0 \\
Lates calcarifer & 933.7 & 1.9 \\
Sllago sihama & 884.5 & 1.8 \\
Etroplus suratensis & 540.5 & 1.1 \\
Macrura kelle & 13022.1 & 26.5 \\
Others & & \\
\hline
\end{tabular}

Table 2 .

The estimated total production by main gear types of the study period is given in

Table 2: Estimated total annual production in metric tons by each main gear type operated in the Chilaw estuary.

\begin{tabular}{lrrrcrrrr}
\hline Station & $\begin{array}{l}\text { Seriya } \\
\text { del }\end{array}$ & $\begin{array}{l}\text { Cast } \\
\text { nets }\end{array}$ & $\begin{array}{l}\text { Drift } \\
\text { nets }\end{array}$ & $\begin{array}{l}\text { Valachchal } \\
\text { nets }\end{array}$ & $\begin{array}{l}\text { Brush } \\
\text { piles }\end{array}$ & $\begin{array}{l}\text { Crab } \\
\text { traps }\end{array}$ & $\begin{array}{l}\text { Stake } \\
\text { seines }\end{array}$ & Total \\
\hline $\begin{array}{l}\text { Pambala } \\
\text { Chilaw }\end{array}$ & - & 7.63 & 3.71 & 6.13 & 4.61 & 5.76 & & 27.84 \\
$\begin{array}{l}\text { market } \\
\text { Karukku }\end{array}$ & 7.15 & 15.60 & 19.53 & - & 0.72 & 17.80 & 25.56 & 86.37 \\
$\begin{array}{l}\text { pane } \\
\text { Total }\end{array}$ & 2.85 & 6.83 & 18.65 & - & 1.86 & 2.03 & 3.95 & 36.18 \\
\hline
\end{tabular}

The highest annual catch of prawns and fish is obtained by stake seines and drift nets respectively whereas the crabs are caught mainly by crab traps (Table 3). 


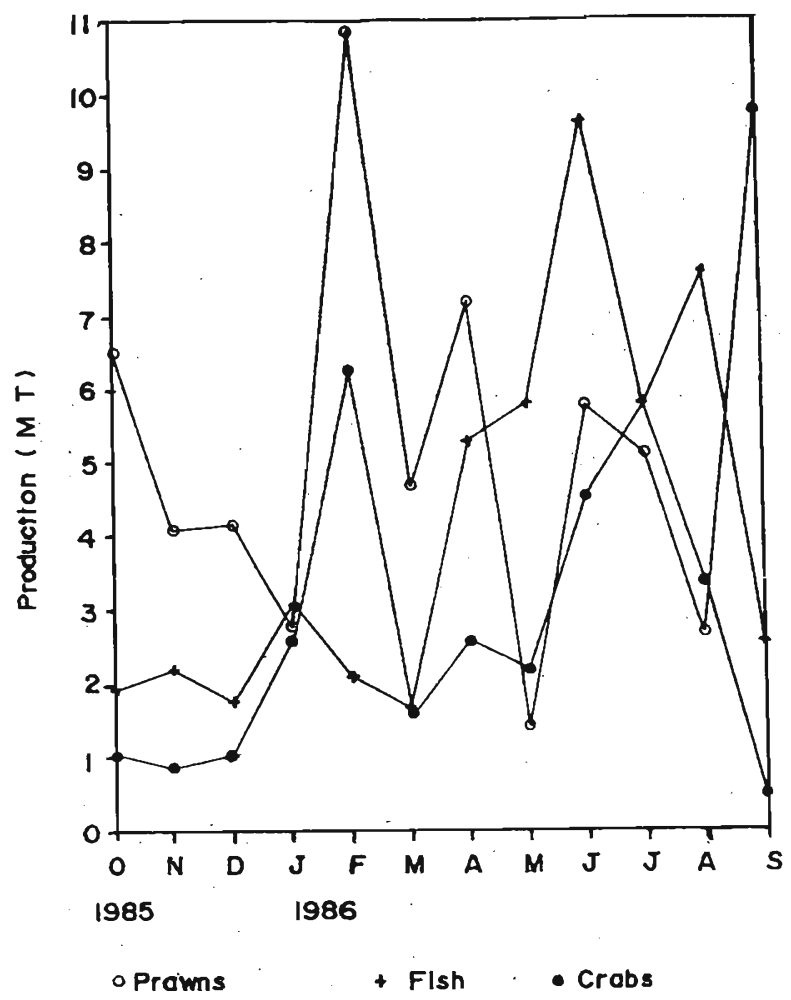

Figure 2: Monthly variation of estimated production of pravns, fish and crabs from the Chilaw lagoon.

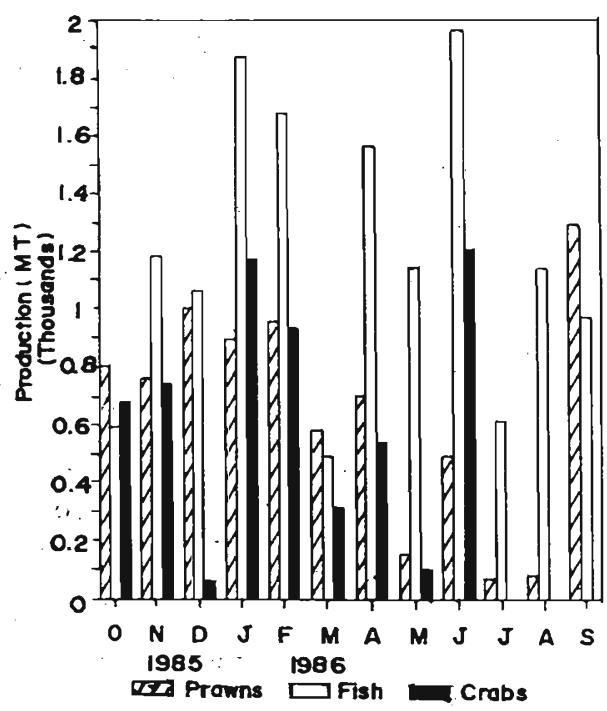

Figure 3: Monthly variation of estimated production of prawns, fish and crabs in Pambala. 


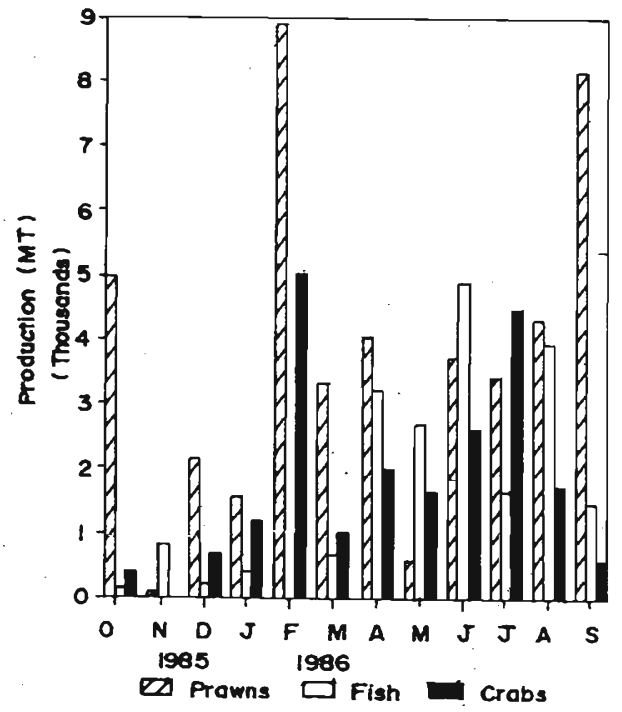

Figure 4: Monthly variation of estimated production of prawns, fish and crabs in Chilaw market.

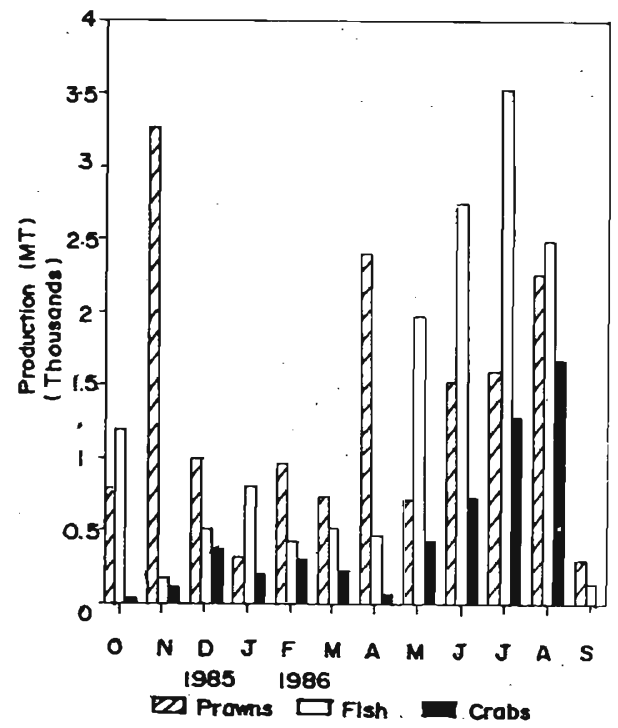

Figure 5: Monthly variation of estimated production of prawns, fish and crabs in Karukkupane. 
Table 3: Estimated total annual production in metric tons of prawns, fish and crabs by different types of gear, operated in the Chilaw estuary

\begin{tabular}{lcrrrrrrr}
\hline Station & $\begin{array}{l}\text { Seriya } \\
\text { del }\end{array}$ & $\begin{array}{l}\text { Cast } \\
\text { nets }\end{array}$ & $\begin{array}{l}\text { Drift } \\
\text { nets }\end{array}$ & $\begin{array}{l}\text { Valachchal } \\
\text { nets }\end{array}$ & $\begin{array}{l}\text { Brush } \\
\text { piles }\end{array}$ & $\begin{array}{l}\text { Crab } \\
\text { traps }\end{array}$ & $\begin{array}{l}\text { Stake } \\
\text { seines }\end{array}$ & Total \\
\hline Prawns & 6.47 & 17.08 & 16.12 & 1.74 & 0.51 & - & 27.11 & 69.04 \\
Fish & 3.53 & 11.04 & 21.36 & 4.39 & 6.68 & - & 2.40 & 49.40 \\
Crabs & - & 1.94 & 4.42 & - & - & 25.59 & 0.58 & 32.53 \\
\hline
\end{tabular}

\section{DISCUSSION}

The prawn catches are high in the months of February and September and low in the months of May and August. This may be because the prawns caught by cast nets, about $25 \%$ of total prawn catch, is low during the monsoonal rains. It becomes difficult to operate cast nets when the estuary is flooded during monsoonal rains.' About $40 \%$ of the total prawn catch comes from stake seines which have been traditionally practised for over one hundred years. The highest catch of fin fish was observed in the month of June. According to Jayasuriya intensive fishing occurs from May to August in the Puttalam lagoon which lies north of Chilaw estuary. 5 The crabs are mainly caught by crab traps, although incidental catches by cast nets, drift nets and stake seines were also observed.

Catches brought to the Chilaw market were always higher than those obtained at other landing sites. This is probably because people from most of the landing sites scattered along the lagoon bring their catch to the Chilaw market, which is the main trade centre in this area. Different types of fishing gear are operated in Pambala, Chilaw and Karukkupane areas. Seriya del is not operated in Pambala area and Valachchal nets are operated only at Pambala. At Karukkupane, stake seines are operated when the mouth of the estuary is not covered by the sand bar. Therefore their operation is seasonal.

The total production of prawns, fish and crabs of the Chilaw lagoon during the period of October 1985 to September 1986 is estimated to be 150.4 MT. Since the area of the Chilaw estuary is $1800 \mathrm{ha}^{8}$ the total production of the Chilaw estuary can be estimated as $83.6 \mathrm{~kg} / \mathrm{ha}$.yr, with prawns, fish and crabs accounting for 38.3,27.3 and $18 \mathrm{~kg} / \mathrm{ha} . \mathrm{yr}$, respectively.

Jayasuriya estimated the total annual production of the Puttalam lagoon to be 49.1 $\mathrm{kg} / \mathrm{ha}$.yr. ${ }^{5}$ According to Wijeyaratne and Costa, the annual fin fish production in the Negombo estuary is around $15 \mathrm{~kg} / \mathrm{ha}$.yr. ${ }^{4}$ Therefore the productivity of the Chilaw estuary is much higher than that of both these lagoons. But in the Negombo estuary, a very large amount of shell fish are also caught. The surface area of the Chilaw estuary is $1800 \mathrm{ha}^{2}$. However, the area of Negombo estuary is $4088 \mathrm{ha}^{4}$ and that of the 
Puttalam lagoon is 23700 ha. $^{5}$ When the annual production values are considered the total production of the Puttalam lagoon is around $1613 \mathrm{MT}^{5}$. In the Negombo estuary the total fin fish production is around $66 \mathrm{MT}^{4}$ In the Chilaw lagoon the production is about $150 \mathrm{MT}$.

The number of fishermen employed in Chilaw estuary is around 500-750, whereas Jayasuriya $^{5}$ reports about 2000 fishermen in the Puttalam lagoon. Because the number of fishermen engaged in the fishing activities is very low, it may appear that fishing activity is less in the Chilaw estuary when compared to other lagoons.

\section{Acknowledgements}

I thank Prof. K.D. Arudpragasam, Chairman, Central Environment Authority for his valuable suggestions in designing this project and in preparing this paper and H.A.R.E. Perera and M.G.K. Gunawardena for their assistance in the field.

\section{References}

1. De Silva S.S. \& De Silva C.D. (1984). Coastal lagoons, in : Ecology and Biogeography in Sri Lanka. Ed. C.H. Fernando. W. Junk Publishers. The Hague, Netherlands.

2. Schuster W.H. (1951). Survey of the inland fisheries of Ceylon government. Publications Bureau, Ceylon. Sessional paper XXIV: 4-15.

3. Pillai T.G. (1965). Brackish-water fishery resources of Ceylon. Bulletin of the Fisheries Research Station of Ceylon 18(2): 75-86.

4. Wijeyaratne M.J.S. \& Costa H.H (1987). On management of the finfish fishery of the Negombo lagoon, Sri Lanka. Indian Joumal of Fisheries 34(1): 41-47.

5. Jayasuriya P.M.A. (1985). The present status of fin fish and crustacean fishery of Puttalam lagoon. Journal of the National Aquatic Resources Agency 32: 94-103.

6. Manisseri M.K. \& Manimaran (1981). On the fishery of the Indian white prawn Penaeus indicus H. Milne Edwards, 1837. FAO Fisheries Report 57(4): $1267-1288$.

7. Siddeek M.S.M. \& Jayakody D.S. An assessment of the stocks of commercially important penaeid prawns in the Chilaw sea (during February), Sri Lanka. Joumal of the National Aquatic Resources Agency (In press).

8. Jayakody D.S. (1984). The fishery and some aspects of biology of commercially important penaeid prawns of the West coast of Sri Lanka. M. Phil. Thesis. University of Kelaniya, Sri Lanka. 119pp.

9. Jayawickrema S.J.C. \& Siddeek M.S.M. Preliminary studies on the surface physico-chemical facctors of Chilaw Lagoon. Joumal of the National Aquatic Resources Agency 33 (In Press). 